\title{
PEMETAAN GURU BAHASA DAN SASTRA SUNDA SMP/MTS DI JAWA BARAT
}

\author{
Ruswendi Permana \\ Departemen Pendidikan Bahasa Daerah FPBS UPI \\ Email: ruswendi.permana@upi.edu
}

\begin{abstract}
Abstrak
Penelitian ini dilatarbelakangi oleh belum adanya informasi pemetaan guru bahasa dan sastra Sunda SMP/MTs di Jawa Barat. Penelitian ini menjawab pertanyaan "Bagaimana kebutuhan guru bahasa dan sastra Sunda SMP/MTs di Jawa Barat?" Metode deskriptif dengan teknik angket dan dokumentasi digunakan dalam penelitian ini. Temuan penelitian ini menunjukkan beberapa hal. Pertama, jumlah sekolah SMP/MTs di Jawa Barat adalah 588 negeri dan 1.979 swasta. Kedua, jumlah siswa SMP/MTs di Jawa Barat adalah SMP/MTs Negeri 76.076 siswa dan SMP/MTs swasta 50.298 siswa. Secara keseluruhan siswa SMP/MTs di Jawa Barat berjumlah 236.850 siswa. Ketiga, jumlah romobongan belajar SMP/MTs adalah 126.374 rombel. Keempat, kebutuhan guru bahasa Sunda di SMP/MTs mencapai 296 guru. Berdasarkan kesimpulan di atas, penelitian ini menyimpulkan bahwa (1) perlu dilakukan pendataan guru bahasa Sunda dengan menggunakan sistem digital mapping guru agar semua guru dapat diakses dan (2) perlu dilakukan penelitian lanjutan yang lebih mendalam dan akurat.
\end{abstract}

Kata kunci: Pemetaan, Kebutuhan Guru, Rombongan Belajar

\section{THE MAPPING OF SUNDANESE LANGUAGE AND LITERATURE TEACHERS AT SMP/MTS IN WEST JAVA}

\begin{abstract}
This research is motivated by the lack of information on the mapping of Sundanese language and literature teacher at Junior High School (SMP) and Madrasah Tsanawiyah (MTs) in West Java. This study answers the question "How is the need of Sundanese language and literature teacher at Junior High School (SMP) and Madrasah Tsanawiyah (MTs) in West Java?" a descriptive method with questionnaires and documentation techniques were used in this study. The findings of this study indicate several things. Firstly, the number of schools (SMP/MTs) in West Java is 588 public and 1,979 private schools. Secondly, the number of students (SMP/MTs) in West Java is 76.076 students of public schools (SMP/MTs) and 50.298 students of private schools (SMP/MTs). The overall number of students (SMP/MTs) in West Java is amounted to 236.850 students. Thirdly, the number of learning group of SMP/MTs is 126.374 groups. Fourthly, the need of Sundanese teacher at SMP/MTs level reaches 296 teachers. Based on the findings, the study concludes that (1) there should be a database of Sundanese language teachers by employing digital mapping system of teachers so that all teachers are accessible; and (2) there is a need of further more in-depth and accurate research.
\end{abstract}

Keywords: Mapping, Need of Teachers, Learning Groups

\section{PENDAHULUAN}

Sejalan dengan bergulirnya Otonomi Daerah (Otda) di Indonesia dalam pembangunan khususnya dalam bidang Pendidikan dihadapkan adanya sejumlah masalah yang harus diantisipasi pemecahannya. Beberapa masalah utama yang memerlukan perhatian dengan saksama adalah potensi dan daya dukung (capacity building) dalam penerapan Otda 
pendidikan itu sendiri. Dari sisi ini berbagai pihak, masyarakat, lembaga pendidikan, kalangan eksekutif, dan legislatif perlu mencermatinya.

Salah satu konsep yang tengah dipersiapkan pada tingkat nasional dalam rangka Otda Pendidikan adalah penerapan Model Manajemen Berbasis Sekolah (MBS). Model yang memberikan kemandirian kepada sekolah dalam pengelolaan sumber daya sekolah mencakup antara lain sarana, personal, keuangan, dan pengembangan kurikulum guna mencapi upaya peningkatan mutu pendidikan. Dalam implementasinya model ini mengharuskan kerjasama yang erat di antara "stakeholders" pendidikan, masyarakat, pemerintah, sekolah (guru, kepala sekolah, staf administrasi), dan siswa. (Umaedi, 1999). Model yang sudah dikembangkan pada tingkat nasional ini (dirintis oleh Tim Teknis Bapenas), pada skala kecil akan dan sedang diujicobakan pada jenjang Pendidikan Dasar di Jawa Barat.

Dalam penerapan (uji coba) model tersebut tentu dipersyaratkan kesiapan lain dari stakeholders (semua unsur yang berkepentingan dalam pendidikan), sekolah dan Indonesia setempat yang memiliki keragaman potensi dan daya dukung kependidikannya. Untuk itu, diperlukan suatu kajian potensi dan daya dukung kependidikan Indonesia dalam penerapan Otda bidang pendidikan yang lebih menyeluruh. Kajian ini akan memfokuskan pada potensi dan daya dukung kependidikan yang berupa kompetensi guru di Jawa Barat. Gambaran ini sangat penting bagi pengambilan kebijakan pengembangan pendidikan di Propinsi Jawa Barat sebagai penyangga utama dalam pengembangan potensi Sumber Daya Manusia (SDM).

Dalam Undang-undang Guru dan Dosen serta PP No. 19 tentang Standar Nasional Pendidikan ditetapkan ada 8 standar, yaitu (1) Standar isi, (2) Standar
Porses, (3) Standar kompetensi lulusan, (4) standar pendidikan dan tenaga kependidikan, (5) Standar sarana dan prasarana, (6) Standar pengelolaan, (7) Standar pembiayaan, serta (8) Standar penilaian.

Perencanaan strategis berkaitan erat dengan program pengembangan kompetensi dan mutu guru bahasa dan sastra Sunda yang dimiliki oleh sekolah dan untuk menelaahnya dapat dilkakukan dengan menelaah program pengembangan staf yang ada di sekolah tersebut beserta aspek-aspek lainnya yang dapat memotivasi peningkatan kualitas kinerja guru, seperti 'reawrd' atau bentuk kompensasi lainnya.

Mariana (2002) memandang bahwa kompetensi profesional guru dapat dilihat dari penguasaan bahan pengajaran, pengelolaan PBM, pengelolaan kelas, penggunaan media/sumber belajar, penguasaan landasan kependidikan, pengelolaan interaksi PBM, pelaksanaan evaluasi pengajaran, pengenalan fungsi layanan BP, pengenalan dan pelaksanaan administrasi sekolah, dan pemahaman prinsip penelitian tindakan kelas.

Guru bahasa dan sastra Sunda sama seperti guru lainnya sebagai tenaga yang profesional dituntut untuk memiliki kompetensi tertentu. Lebih lanjut kompetensi yang harus dipenuhi oleh seroang guru yaitu memiliki profil tenaga kependidikan yang profesional. Guru yang professional memiliki profil keguruan yang professional pula. Oleh karena itu, profil guru dapat dikatakan sebagai potret keadaan yang sebenarnya yang dimiliki oleh guru, yang dapat dilihat dari berbagai aspek, di antaranya adalah (a) pengalaman mengajar, (b) pendidikan tertinggi, dan (c) kualifikasi kependidikan.

Guru sebagai seorang pendidik dan pembimbing dikatakan berhasil bila dapat menunjukkan prestasi dalam menghantarkan para siswanya ke arah yang lebih baik dibandingkan dengan sebelum 
siswa yang bersangkutan menjadi anak didiknya. Prestasi yang dimaksudkan adalah prestasi yang ditampilkan setelah guru yang bersangkutan menerima tanggung jawabnya dalam bentuk tugas pekerjaan yang harus dilaksanakannya.

Di samping itu, ada hal lain yang berpengaruh terhadap prestasi belajar siswa yaitu kinerja guru dalam pelaksanaan kegiatan belajar mengajar di kelas. Dengan kata lain, seorang guru dapat berkerja dengan disiplin penuh tanggung jawab. Hal ini sesuai dengan pendapat yang menyatakan bahwa, profil guru merupakan serangkaian kegiatan yang bersifat sebagai pengendalian yang terus menerus dilakukan agar dalam melaksanakan tugas berjalan secara efektif, dan efesien dengan rencana kegiatan, dan ketentuan peraturan perundang-undangan yang berlaku. Begitupun halnya dengan profil dan kinerja guru yang baik cukup berpengaruh terhadap prestasi belajar para siswanya.

Dalam rangka menghadapi dan mengantisipasi era globalisasi dengan ciri utama persaingan bebas yang semakin ketat, kompetitif, dan saling ketergantungan yang semakin kuat, pemerintah telah berupaya untuk melakukan berbagai cara, di antaranya adalah memajukan kesejahteraan umum dan mencerdaskan kehidupan bangsa. Bangsa yang cerdas, beradab, berbudaya, dan maju akan dapat menghadapi permasalahan masa depan bangsa Indonesia. Upaya ini telah digariskan dalam UUD 1945 sebagai salah satu citacita bangsa Indonesia, yaitu memajukan kesejahteraan umum dan mencerdaskan kehidupan bangsa.

Dalam rangka merealisasikan cita-cita tersebut, pemerintah telah menjabarkannya ke dalam UU No. 20 Tahun 2003 yang dijadikan legalitas Sistem Pendidikan Nasional. Sistem Pendidikan Nasional tersebut memegang peranan penting dalam meningkatkan kualitas sumber daya manusia (SDM) Indonesia yang bermartabat dan berakhlak mulia. Bahkan dalam Propenas (Program Pembangunan Nasional) telah digariskan bahwa ada empat strategi pokok yang dikembangkan dalam merealisasikan sistem pendidikan nasional, yaitu (a) pemerataan kesempatan pendidikan, (b) relevansi, (c) kualitas, dan (c) efisiensi.

Setelah itu, pemerintah telah mengeluarkan PP Nomor 19 Tahun 2005 tentang Standar Nasional Pendidikan yang mencakup delapan standar, yaitu standar isi, standar proses, standar kompetensi lulusan, standar pendidik dan tenaga kependidikan, standar pengelolaan, standar pembiayaan, dan standar penilaian pendidikan.

Dalam PP 19 tahun 2005 Bab VI, Pasal 28 dijelaskan bahwa (1) pendidikan harus memiliki kualifikasi akademik dan kompetensi sebagai agen pembelajaran, sehat jasmani dan rohani, serta memiliki kemampuan untuk mewujudkan tujuan pendidikan nasional; (2) kualifikasi akademik sebagaimana yang harus dipenuhi pada ayat (1) adalah tingkat pendidikan minimal yang harus dipenuhi oleh seorang pendidik yang dibuktikan dengan ijazah dan/atau sertifikasi keahlian yang harus relevan sesuai dengan ketentuan perundang-undangan yang berlaku; (3) kompetensi sebagai agen pembelajaran pada jenjang pendidikan dasar dan menengah serta pendidikan anak usia dini PAUD) yang meliputi (a) kompetensi pedagogik, (b) kompetensi kepribadian, (c) kompetensi profesional, dan (d) kompetensi sosial.

Kompetensi pedagogik meliputi pemahaman terhadap peserta didik, perancangan dan pelaksanaan pembelajaran, penilaian hasil belajar, dan pengembangan peserta didik untuk mengaktualisasikan potensi yang dimilikinya. Kompetensi kepribadian meliputi kemampuan kepribadian yang mantap, stabil, dewasa, arif, dan 
berwibawa, menjadi teladan bagi peserta didik dan berakhlak mulia.

Kompetensi profesional meliputi penguasaan materi pembelajaran secara luas dan mendalam yang memungkinkan guru dan tenaga pendidik lainnya membimbing peserta didik memenuhi standar kompetensi yang ditetapkan dalam Standar Nasional Pendidikan. Kompetensi sosial meliputi kemampuan guru dan tenaga pendidik sebagai anggota masyarakat untuk berkomunikasi dan bergaul secara komunikatif dan efektif dengan peserta didik, sesama pendidik, tenaga kependidikan, orang tua/wali murid, dan masyarakat sekitar.

Berdasarkan uraian di atas, maka program pendidikan sertifikasi guru dalam prajabatan Mata Pelajaran Bahasa dan Sastra Sunda di Jawa Barat perlu dilakukan agar diperoleh tenaga guru yang standar sesuai dengan tuntutan Undang-Undang No. 14 tentang Guru dan Dosen serta Peraturan Pemerintah Nomor 19 Tahun 2005, tentang Standar Nasional Pendidikan (SNP).

Berdasarkan Surat Keputusan Gubernur Jawa Barat tentang Standar Kompetensi dan Kompetensi Dasar Mata Pelajaran Bahasa dan Sastra Sunda tahun 2006, mata pelajaran bahasa Sunda wajib diajarkan dari mulai TK sampai SMP/MTS/SMK/MA. Oleh karena itu, guru bahasa Sunda sangat dibutuhkan. Akan tetapi, pada kenyataannya guru bahasa dan sastra Sunda di SMP/MTS Jawa Barat sampai saat ini belum teridentifikasi dan terpetakan dengan baik.

Sampai saat ini informasi data kebutuhan guru bahasa dan sastra di SMP/MTS Jawa Barat belum ada. Jumlah sekolah dan jumlah rombongan belajar merupakan salah satu komponen dalam menentukan kebutuhan guru. Masalah dalam penelitian ini meliputi (a) jumlah guru yang tersedia saat ini, (b) jumlah rombongan belajar dan sekolah yang ada di Kota Bandung, (c) jumlah kebutuhan guru bahasa dan sastra Sunda sesuai dengan jumlah rombongan belajar, (d) kualifikasi guru bahasa dan sastra Sunda sampai saat ini, (e) penyebebaran atau distribusi keadaan kebutuhan guru di masing-masing sekolah.

\section{METODE}

Penelitian ini menggunakan metode deskriptif. Menurut Stephen (1981) metode ini digunakan untuk (a) mengumpulkan informasi faktual secara rinci dan menggambarkan gejala-gejala yang ada, (b) mengidentifikasi masalah-masalah yang ada sekarang, (c) membuat perbandingan-perbandingan, dan (d) menentukan apa saja yang dapat diambil atau apa implikasinya dari pengalaman itu bagi perencanaan dan keputusan-keputusan di masa yang akan datang.

Dalam penelitian ini pun digunakan metode statistik deskriptif dan metode statistik inferensial (Rochman, 1988:1). Metode satistik deskriptif digunakan untuk menghitung dan melaporkan prediksi kebutuhan guru bahasa dan sastra Sunda lima tahun yang akan datang.

Teknik pengumpulan data dalam penelitian terdiri atas (1) angket, yang digunakan untuk mengumpulkan data profil dan kebutuhan guru bahasa dan sastra Sunda; dan (2) studi dokumentasi, yang digunakan untuk mengetahui jumlah rombongan belajar dan jumlah sekolah SMP/MTs di Jawa Barat.

Teknik pengolahan data yang digunakan dengan menggunakan perhitungan jumlah romongan belajar dan jumlah kebutuhan guru berdasarkan ekuavalensi kewajiban mengajar 24 jam pelajaran. Rumus perhitungannya adalah sebagai berikut.

\section{HASIL DAN PEMBAHASAN \\ Pengetahuan dan Pemahaman Guru tentang Acuan Pembelajaran Bahasa dan Sastra Sunda}

Berdasarkan hasil angket, pengetahuan dan pemahaman guru tentang 
acuan pembelajaran bahasa dan sastra

Sunda dapat dilihat pada tabel berikut ini.

\section{Tabel 1 \\ Pengetahuan dan Pemahaman Guru tentang Acuan Pembelajaran Bahasa dan Sastra Sunda}

\begin{tabular}{|c|c|c|c|c|}
\hline No & Aspek yang Ditanyakan & Kriteria & $f$ & $\%$ \\
\hline \multirow[t]{3}{*}{1} & \multirow{3}{*}{$\begin{array}{l}\text { Pengetahuan dan pemahaman guru tentang } \\
\text { Standar Kompetensi dan Kompetensi Dasar Mata } \\
\text { Pelajaran Bahasa dan Sastra Sunda }\end{array}$} & Sudah & 3 & 7 \\
\hline & & Belum & 15 & 35 \\
\hline & & Tahu sedikit & 25 & 58 \\
\hline \multirow[t]{4}{*}{2} & \multirow{4}{*}{$\begin{array}{l}\text { Pengetahuan dan pemahaman guru tentang } \\
\text { pengembangan dan penyusunan silabus dan sistem } \\
\text { penilaian }\end{array}$} & Sudah & 14 & 33 \\
\hline & & Belum & 11 & 26 \\
\hline & & Baru sedikit & 18 & 42 \\
\hline & & Tidak Tahu & - & - \\
\hline \multirow[t]{4}{*}{3} & \multirow{4}{*}{$\begin{array}{l}\text { Pengetahuan dan pemahaman guru dalam } \\
\text { mengembangkan dan menyusun bahan ajar bahasa } \\
\text { dan sastra Sunda }\end{array}$} & Sudah & 38 & 88 \\
\hline & & Belum & 1 & 2 \\
\hline & & Baru sedikit & 1 & 2 \\
\hline & & Tidak Tahu & 3 & 7 \\
\hline \multirow[t]{3}{*}{4} & \multirow{3}{*}{$\begin{array}{l}\text { Penyusunan bahan ajar bahasa daerah didasarkan } \\
\text { pada prinsip kemudahan dan kemanfaatannya }\end{array}$} & $\mathrm{Ya}$ & 41 & 95 \\
\hline & & Tidak & 1 & 2 \\
\hline & & Tidak Tahu & - & - \\
\hline \multirow[t]{3}{*}{5} & \multirow{3}{*}{$\begin{array}{l}\text { Penyusunan bahan ajar bahasa dan sastra Sunda } \\
\text { sesuai dengan kebutuhan siswa }\end{array}$} & $\mathrm{Ya}$ & - & - \\
\hline & & Tidak & - & - \\
\hline & & Tidak Tahu & - & - \\
\hline \multirow[t]{3}{*}{6} & \multirow{3}{*}{$\begin{array}{l}\text { Dalam proses pembelajaran selalu menggunakan } \\
\text { buku teks dan LKS }\end{array}$} & $\mathrm{Ya}$ & 26 & 60 \\
\hline & & $\begin{array}{l}\text { Kadang- } \\
\text { kadang }\end{array}$ & 13 & 30 \\
\hline & & Tidak & 4 & 9 \\
\hline \multirow[t]{3}{*}{7} & \multirow{3}{*}{$\begin{array}{l}\text { Bahasa pengantar dalam pembelajaran bahasa } \\
\text { Sunda selalu menggunakan bahasa Sunda }\end{array}$} & $\mathrm{Ya}$ & 32 & 74 \\
\hline & & Tidak & - & - \\
\hline & & $\begin{array}{l}\text { Kadang- } \\
\text { kadang }\end{array}$ & 11 & 26 \\
\hline \multirow[t]{3}{*}{8} & \multirow{3}{*}{$\begin{array}{l}\text { Bahasa Sunda baku (lulugu) dan bukan bahasa } \\
\text { dialek (wewengkon) yang diajarkan kepada siswa. }\end{array}$} & $\mathrm{Ya}$ & 27 & 63 \\
\hline & & Tidak & 8 & 19 \\
\hline & & $\begin{array}{l}\text { Kadang- } \\
\text { kadang }\end{array}$ & 8 & 19 \\
\hline \multirow[t]{3}{*}{9} & \multirow{3}{*}{$\begin{array}{l}\text { Dalam pelaksanaan pembelajaran bahasa dan } \\
\text { sastra Sunda kurang memperhatikan keterampilan } \\
\text { berbahasa (menyimak, berbicara, membaca, dan } \\
\text { menulis) }\end{array}$} & $\mathrm{Ya}$ & 20 & 47 \\
\hline & & Tidak & 14 & 33 \\
\hline & & $\begin{array}{l}\text { Kadang- } \\
\text { kadang }\end{array}$ & 9 & 22 \\
\hline \multirow[t]{3}{*}{10} & \multirow{3}{*}{$\begin{array}{l}\text { Dalam pelaksanaan pembelajaran bahasa dan } \\
\text { sastra Sunda selalu menggunakan bahasa yang } \\
\text { santun sesuai dengan tatakrama atau undak-usuk } \\
\text { bahasa }\end{array}$} & $\mathrm{Ya}$ & 18 & 42 \\
\hline & & Tidak & 6 & 14 \\
\hline & & $\begin{array}{l}\text { Kadang- } \\
\text { kadang }\end{array}$ & 21 & 45 \\
\hline \multirow[t]{3}{*}{11} & \multirow[t]{3}{*}{ Materi aksara Sunda "Kaganga" selalu diajarkan } & $\mathrm{Ya}$ & 5 & 12 \\
\hline & & Tidak & 34 & 79 \\
\hline & & & 4 & \\
\hline
\end{tabular}




\begin{tabular}{|c|c|c|c|c|}
\hline No & Aspek yang Ditanyakan & Kriteria & $f$ & $\%$ \\
\hline & & kadang & & \\
\hline \multirow[t]{3}{*}{12} & \multirow[t]{3}{*}{ Materi pupuh dan kakawihan selalu diajarkan. } & $\mathrm{Ya}$ & 10 & 23 \\
\hline & & Tidak & 18 & 42 \\
\hline & & $\begin{array}{l}\text { Kadang- } \\
\text { kadang }\end{array}$ & 15 & 35 \\
\hline \multirow[t]{3}{*}{13} & \multirow{3}{*}{$\begin{array}{l}\text { Dalam pelaksanaan pembelajaran bahasa dan } \\
\text { sastra Sunda selalu menggunakan berbagai sumber } \\
\text { belajar }\end{array}$} & $\mathrm{Ya}$ & 27 & 63 \\
\hline & & Tidak & 7 & 16 \\
\hline & & $\begin{array}{l}\text { Kadang- } \\
\text { kadang }\end{array}$ & 7 & 16 \\
\hline
\end{tabular}

Berdasarkan tabel di atas, maka pengetahuan dan pemahaman guru tentang acuan pembelajaran bahasa dan sastra Sunda, adalah sebagai berikut.

Hanya sebagian kecil saja responden (7\%) yang telah mengetahui dan paham tentang standar kompetensi dan kompetensi dasar mata pelajaran bahasa dan sastra Sunda, sedangkan sebagian besar responden $(58 \%)$ baru mengetahui sedikit, dan sebagian responden lainnya (35\%) belum mengetahui sama sekali.

Sebagian responden (33\%) telah mengetahui dan paham tentang pengembangan dan penyusunan silabus dan sitem penilaian, sedangkan sebagian lainnya (42\%) baru mengetahui dan paham sedikit, serta sebagian kecil responden (26\%) belum mengetahui sama sekali.

Sebagian besar responden $(88 \%)$ telah mengetahui dan paham dalam mengembangkan dan menyusun bahan ajar bahasa dan sastra Sunda, sedangkan sebagian kecil responden (2\%) baru mengetahui sedikit, dan sebagian kecil lainnya $(2 \%)$ belum mengetahui, serta sebagian lainnya lagi (7\%) tidak tahu dan tidak paham sama sekali.

Hampir semua responden (98\%) menyatakan bahwa penyusunan bahan ajar bahasa dan sastra Sunda didasarkan pada prinsip kemudahan dan kemanfaatannya, dan hanya sebagian kecil responden $(2 \%)$ yang menyatakan tidak.

Sebagian besar responden (60\%) selalu menggunakan buku teks dan LKS dalam proses pembelajaran, sedangkan sebagian lainnya (30\%) hanya kadangkadang saja, serta sebagian kecil responden tidak pernah menggunakan buku teks dan LKS.

Bahasa Sunda digunakan oleh sebagian besar responden (74\%) sebagai bahasa pengantar dalam proses pembelajaran, sedangkan sebagian lainnya (26\%) hanya kadang-kadang saja penggunaannya.

Adapun bahasa Sunda yang diajarkan di sekolah, ternyata sebagian besar responden $(63 \%)$ mengajarkan bahasa Sunda baku (lulugu), dan sebagian lainnya (19\%) tidak mengajarkannya, serta sebagian lainnya lagi (19\%) hanya mengajarkannya sekali-sekali saja.

Sebagian besar responden (47\%) kurang memperhatikan aspek keterampilan berbahasa (menyimak, berbicara, membaca, dan menulis) dalam pelaksanaan pembelajaran bahasa dan sastra Sunda, sedangkan sebagian lainnya (33\%) telah memperhatikan aspek tersebut, dan sebagian kecil responden (22\%) hanya kadang-kadang saja memperhatikan aspek tersebut.

Dalam pembelajaran bahasa dan sastra Sunda, hanya sebagian $(42 \%)$ yang menggunakan tatakrama atau undak-usuk bahasa, sedangkan sebagian besar responden $(45 \%)$ hanya kadang-kadang menggunakannya, dan sebagian kecil lainnya (14\%) tidak pernah menggunakan tatakrama atau undak usuk tersebut.

Sebagian besar responden (79\%) tidak pernah mengajarkan aksara Sunda 
"Kaganga", dan hanya sebagian kecil (12\%) yang selalu mengajarkannya, serta sebagioan kecil lainnya (9\%) hanya kadang-kadang saja mengajarkannya.

Demikian juga materi pengajaran pupuh dan kakawihan, tidak pernah diajarkan oleh sebagian besar responden $(42 \%)$, dan hanya diajarkan oleh sebagian kecil responden (23\%), serta hanya diajarkan kadang-kadang oleh responden lainnya (35\%).

Penggunaan berbagai sumber belajar dalam pengajaran basa dan sastra Sunda telah dilakukan oleh sebagian besar responden $(63 \%)$, dan hanya sebagian kercil responden (16\%) yang tidak menggunakannya, serta sebagian responden lainnya (16\%) hanya kadangkadang saja menggunakannya.

\section{Sikap terhadap Pendidikan Bahasa dan Sastra Sunda}

Berdasarkan angket, sikap responden terhadap pendidikan bahasa dan sastra Sunda di sekolah dapat dilihat pada tabel berikut.

Tabel 2

Sikap Pendidik terhadap Pendidikan Bahasa dan Sastra Sunda

\begin{tabular}{|c|c|c|c|c|}
\hline No & Aspek yang Digali/Diukur & Kriteria & $\mathbf{f}$ & $\%$ \\
\hline \multirow[t]{5}{*}{1} & \multirow{5}{*}{$\begin{array}{l}\text { Bahasa dan sastra Sunda perlu } \\
\text { diperkenalkan dari TK sampai SMA }\end{array}$} & Setuju Sekali & 26 & 72 \\
\hline & & Setuju & 9 & 25 \\
\hline & & Biasa-biasa saja & - & - \\
\hline & & Kurang Setuju & 1 & 3 \\
\hline & & Tidak Setuju & - & - \\
\hline \multirow[t]{5}{*}{2} & \multirow{5}{*}{$\begin{array}{l}\text { Selain di SMA, bahasa dan sastra } \\
\text { Sunda pun perlu diajarkan di SMK }\end{array}$} & Setuju Sekali & 25 & 69 \\
\hline & & Setuju & 9 & 25 \\
\hline & & Biasa-biasa saja & - & - \\
\hline & & Kurang Setuju & - & - \\
\hline & & Tidak Setuju & - & - \\
\hline \multirow[t]{5}{*}{3} & \multirow{5}{*}{$\begin{array}{l}\text { Bahasa dan sastra Sunda tidak perlu } \\
\text { diajarkan karena tidak penting } \\
\text { dibandingkan dengan mata pelajaran } \\
\text { lainnya. }\end{array}$} & Setuju Sekali & 4 & 11 \\
\hline & & Setuju & 11 & 31 \\
\hline & & Biasa-biasa saja & 5 & 14 \\
\hline & & Kurang Setuju & 1 & 3 \\
\hline & & Tidak Setuju & 15 & 42 \\
\hline \multirow[t]{5}{*}{4} & \multirow{5}{*}{$\begin{array}{l}\text { Bahasa Sunda tidak diajarkan karena } \\
\text { menyulitkan siswa }\end{array}$} & Setuju Sekali & 4 & 11 \\
\hline & & Setuju & 9 & 25 \\
\hline & & Biasa-biasa saja & 2 & 6 \\
\hline & & Kurang Setuju & 3 & 8 \\
\hline & & Tidak Setuju & 18 & 50 \\
\hline \multirow[t]{5}{*}{5} & \multirow{5}{*}{$\begin{array}{l}\text { Bahasa dan sastra Sunda tidak sempat } \\
\text { diajarkan karena waktunya habis oleh } \\
\text { mata pelajaran lainnya. }\end{array}$} & Setuju Sekali & 5 & 14 \\
\hline & & Setuju & 18 & 50 \\
\hline & & Biasa-biasa saja & 1 & 3 \\
\hline & & Kurang Setuju & 4 & 11 \\
\hline & & Tidak Setuju & 8 & 22 \\
\hline \multirow[t]{4}{*}{6} & \multirow{4}{*}{$\begin{array}{l}\text { Bahasa dan sastra Sunda tidak } \\
\text { diajarkan karena tidak tersedianya } \\
\text { buku sumber. }\end{array}$} & Setuju Sekali & - & - \\
\hline & & Setuju & 3 & 8 \\
\hline & & Biasa-biasa saja & - & - \\
\hline & & Kurang Setuju & 7 & 19 \\
\hline
\end{tabular}




\begin{tabular}{|c|c|c|c|c|}
\hline No & Aspek yang Digali/Diukur & Kriteria & $\mathbf{f}$ & $\%$ \\
\hline & & Tidak Setuju & 26 & 72 \\
\hline \multirow[t]{5}{*}{7} & \multirow{5}{*}{$\begin{array}{l}\text { Saya tidak berani mengajarkan bahasa } \\
\text { dan sastra Sunda karena bukan asli } \\
\text { orang Sunda }\end{array}$} & Setuju Sekali & - & - \\
\hline & & Setuju & - & - \\
\hline & & Biasa-biasa saja & - & - \\
\hline & & Kurang Setuju & 12 & 33 \\
\hline & & Tidak Setuju & 24 & 67 \\
\hline \multirow[t]{5}{*}{8} & \multirow{5}{*}{$\begin{array}{l}\text { Saya mengutamakan mata pelajaran } \\
\text { yang di-UAN-kan daripada mata } \\
\text { pelajaran bahasa dan sastra Sunda }\end{array}$} & Setuju Sekali & - & - \\
\hline & & Setuju & - & - \\
\hline & & Biasa-biasa saja & 2 & 6 \\
\hline & & Kurang Setuju & 2 & 6 \\
\hline & & Tidak Setuju & 14 & 39 \\
\hline \multirow[t]{5}{*}{9} & \multirow{5}{*}{$\begin{array}{l}\text { Bahasa dan sastra Sunda diajarkan } \\
\text { ketika akan menghadapi ujian atau } \\
\text { THB. }\end{array}$} & Setuju Sekali & 9 & 25 \\
\hline & & Setuju & 7 & 19 \\
\hline & & Biasa-biasa saja & 4 & 11 \\
\hline & & Kurang Setuju & 12 & 33 \\
\hline & & Tidak Setuju & 4 & 11 \\
\hline \multirow[t]{5}{*}{10} & \multirow{5}{*}{$\begin{array}{l}\text { Buku sumber yang berbahasa Sunda di } \\
\text { perpustakaan sekolah cukup lengkap. }\end{array}$} & Setuju Sekali & 8 & 22 \\
\hline & & Setuju & 7 & 19 \\
\hline & & Biasa-biasa saja & 4 & 11 \\
\hline & & Kurang Setuju & 12 & 33 \\
\hline & & Tidak Setuju & 5 & 14 \\
\hline \multirow[t]{5}{*}{11} & \multirow{5}{*}{$\begin{array}{l}\text { Media pembelajaran atau alat peraga } \\
\text { pembelajaran bahasa dan sastra Sunda } \\
\text { di sekolah kurang lengkap. }\end{array}$} & Setuju Sekali & 4 & 11 \\
\hline & & Setuju & 11 & 31 \\
\hline & & Biasa-biasa saja & 2 & 6 \\
\hline & & Kurang Setuju & 8 & 22 \\
\hline & & Tidak Setuju & 10 & 28 \\
\hline \multirow[t]{5}{*}{12} & \multirow{5}{*}{$\begin{array}{l}\text { Buku penunjang atau pendukung mata } \\
\text { pelajaran bahasa dan sastra Sunda } \\
\text { tidak ada. }\end{array}$} & Setuju Sekali & 1 & 3 \\
\hline & & Setuju & 3 & 8 \\
\hline & & Biasa-biasa saja & 2 & 6 \\
\hline & & Kurang Setuju & 6 & 17 \\
\hline & & Tidak Setuju & 24 & 67 \\
\hline \multirow[t]{5}{*}{13} & \multirow{5}{*}{$\begin{array}{l}\text { Buku penunjang atau pendukung mata } \\
\text { pelajaran bahasa dan sastra Sunda } \\
\text { perlu disediakan di sekolah. }\end{array}$} & Setuju Sekali & 22 & 66 \\
\hline & & Setuju & 9 & 25 \\
\hline & & Biasa-biasa saja & - & - \\
\hline & & Kurang Setuju & 2 & 6 \\
\hline & & Tidak Setuju & 1 & 3 \\
\hline \multirow[t]{5}{*}{14} & \multirow{5}{*}{$\begin{array}{l}\text { Saya mengalami kesulitan dalam } \\
\text { melaksanakan pembelajaran bahasa } \\
\text { dan sastra Sunda }\end{array}$} & Setuju Sekali & 5 & 14 \\
\hline & & Setuju & 11 & 31 \\
\hline & & Biasa-biasa saja & 1 & 3 \\
\hline & & Kurang Setuju & 13 & 36 \\
\hline & & Tidak Setuju & 5 & 14 \\
\hline \multirow[t]{4}{*}{15} & \multirow{4}{*}{$\begin{array}{l}\text { Saya lancar mengajarkan bahasa dan } \\
\text { sastra Sunda. }\end{array}$} & Setuju Sekali & 3 & 8 \\
\hline & & Setuju & 18 & 50 \\
\hline & & Biasa-biasa saja & 6 & 17 \\
\hline & & Kurang Setuju & 6 & 17 \\
\hline
\end{tabular}




\begin{tabular}{|c|c|c|c|c|}
\hline No & Aspek yang Digali/Diukur & Kriteria & $\mathbf{f}$ & $\%$ \\
\hline & & Tidak Setuju & 1 & 3 \\
\hline \multirow[t]{5}{*}{16} & \multirow{5}{*}{$\begin{array}{l}\text { Saya sangat senang mengajarkan } \\
\text { bahasa dan sastra Sunda kepada siswa. }\end{array}$} & Setuju Sekali & 8 & 22 \\
\hline & & Setuju & 18 & 50 \\
\hline & & Biasa-biasa saja & 4 & 11 \\
\hline & & Kurang Setuju & 6 & 17 \\
\hline & & Tidak Setuju & - & - \\
\hline \multirow[t]{5}{*}{17} & \multirow{5}{*}{$\begin{array}{l}\text { Menurut pengamatan saya siswa } \\
\text { senang mengikuti pelajaran bahasa dan } \\
\text { sastra Sunda }\end{array}$} & Setuju Sekali & 5 & 14 \\
\hline & & Setuju & 16 & 44 \\
\hline & & Biasa-biasa saja & 14 & 39 \\
\hline & & Kurang Setuju & 1 & 3 \\
\hline & & Tidak Setuju & - & - \\
\hline \multirow[t]{5}{*}{18} & \multirow{5}{*}{$\begin{array}{l}\text { Di sekolah (SD/MI) perlu ada guru } \\
\text { khusus mata pelajaran bahasa dan } \\
\text { sastra Sunda }\end{array}$} & Setuju Sekali & 16 & 44 \\
\hline & & Setuju & 14 & 33 \\
\hline & & Biasa-biasa saja & 2 & 6 \\
\hline & & Kurang Setuju & 3 & 8 \\
\hline & & Tidak Setuju & - & - \\
\hline \multirow[t]{5}{*}{19} & \multirow{5}{*}{$\begin{array}{l}\text { Saya sangat memahami alasan } \\
\text { pentingnya menggunakan bahasa dan } \\
\text { sastra Sunda sebagai bahasa pengantar } \\
\text { di sekolah tingkat rendah }\end{array}$} & Setuju Sekali & 14 & 39 \\
\hline & & Setuju & 16 & 44 \\
\hline & & Biasa-biasa saja & 3 & 8 \\
\hline & & Kurang Setuju & 3 & 8 \\
\hline & & Tidak Setuju & - & - \\
\hline \multirow[t]{5}{*}{20} & \multirow{5}{*}{$\begin{array}{l}\text { Bahasa Sunda sebaiknya digunakan } \\
\text { dalam komunikasi di lingkungan } \\
\text { keluarga walaupun dicampur dengan } \\
\text { bahasa lain. }\end{array}$} & Setuju Sekali & 1 & 3 \\
\hline & & Setuju & 5 & 14 \\
\hline & & Biasa-biasa saja & 3 & 8 \\
\hline & & Kurang Setuju & 18 & 50 \\
\hline & & Tidak Setuju & 9 & 25 \\
\hline \multirow[t]{5}{*}{21} & \multirow{5}{*}{$\begin{array}{l}\text { Saya juga menggunakan bahasa } \\
\text { Indonesia sebagai bahasa pengantar } \\
\text { dalam mengajarkan bahasa dan sastra } \\
\text { Sunda }\end{array}$} & Setuju Sekali & 5 & 14 \\
\hline & & Setuju & 8 & 22 \\
\hline & & Biasa-biasa saja & 8 & 22 \\
\hline & & Kurang Setuju & 8 & 22 \\
\hline & & Tidak Setuju & 7 & 19 \\
\hline \multirow[t]{5}{*}{22} & \multirow{5}{*}{$\begin{array}{l}\text { Saya tidak mengetahui bahwa } \\
\text { peraturan penggunaan bahasa dan } \\
\text { sastra Sunda di kelas awal SD }\end{array}$} & Setuju Sekali & 4 & 11 \\
\hline & & Setuju & 11 & 31 \\
\hline & & Biasa-biasa saja & 4 & 11 \\
\hline & & Kurang Setuju & 13 & 36 \\
\hline & & Tidak Setuju & 3 & 8 \\
\hline \multirow[t]{5}{*}{23} & \multirow{5}{*}{$\begin{array}{l}\text { Penataran dan penyuluhan bahasa dan } \\
\text { sastra Sunda perlu dilaksanakan bagi } \\
\text { guru-guru. }\end{array}$} & Setuju Sekali & 23 & 64 \\
\hline & & Setuju & 13 & 36 \\
\hline & & Biasa-biasa saja & - & - \\
\hline & & Kurang Setuju & - & - \\
\hline & & Tidak Setuju & - & - \\
\hline
\end{tabular}

Berdasarkan tabel di atas, maka sikap guru terhadap pendidikan bahasa dan sastra Sunda, adalah sebagai berikut.
Sebagian besar responden (72\%) menyatakan setuju sekali bahwa bahasa dan sastra Sunda perlu diperkenalkan dari TK sampai SMA, sedangkan sebagian 
lainnya (25\%) menyatakan setuju, dan sebagian kecil responden (3\%) menyatakan kurang setuju.

Sebagian besar responden $(69 \%)$ menyatakan setuju sekali bahwa selain di SMA, bahasa dan sastra Sunda perlu pula diajarkan di SMK, sedangkan sebagian kecil responden (25\%) menyatakan setuju, dan tidak ada satu pun responden yang menyatakan kurang atau tidak setuju.

Sebagian besar responden (42\%) menyatakan tidak setuju jika bahasa dan sastra Sunda tidak perlu diajarkan karena dianggap tidak penting dibandingkan dengan mata pelajaran lainnya, sedangkan sebagian kecil responden (3\%) menyatakan kurang setuju, sebagian lainnya (14\%) biasa-biasa saja, sebagian responden lainnya lagi (31\%) setuju, dan sisanya (11\%) menyatakan setuju sekali.

Sebagian besar responden (50\%) menyatakan tidak setuju jika bahasa Sunda tidak diajarkan karena dianggap menyulitkan siswa, sedangkan sebagian kecil responden (8\%) menyatakan kurang setuju, sebagian kecil responden lainnya (6\%) menyatakan biasa-biasa saja, dan sebagian responden lainnya lagi $(25 \%)$ menyatakan setuju, serta sisanya (11\%) menyatakan setuju sekali.

Bahasa dan sastra Sunda tidak sempat diajarkan karena waktunya habis oleh mata pelajaran yang lain. Terhadap hal tersebut, sebagian besar responden $(50 \%)$ menyatakan setuju, sebagian responden (14\%) setuju sekali, sebagian kecil responden $(11 \%)$ kurang setuju, sebagian kecil responden lainnya (3\%) menyatakan biasa-biasa saja, dan sisanya (22\%) menyatakan setuju sekali.

Sebagian besar responden (72\%) menyatakan tidak setuju jika bahasa dan sastra Sunda tidak diajarkan karena tidak tersedianya buku sumber, sedangkan sebagian kecil responden (19\%) menyatakan kurang setuju, dan sebgaian kecil responden lainnya $(8 \%)$ menyatakan setuju.
Sebagian besar responden (67\%) menyatakan tidak setuju jika guru tidak berani mengajarkan bahasa dan sastra Sunda karena dia bukan asli orang Sunda, dan sebagian responden lainnya (33\%) menyatakan kurang setuju, serta tidak ada satu pun responden yang menyatakan setuju atau setuju sekali.

Sebagian besar responden (39\%) menyatakan tidak setuju jika mata pelajaran yang di-UAN-kan lebih diutamakan daripada mata pelajaran bahasa dan sastra Sunda, sebagian kecil responden $(6 \%)$ menyatakan kurang setuju, dan sebagian kecil responden lainnya (6\%) menyatakan biasa-biasa saja, serta tidak ada satu pun responden yang menyatakan setuju atau setju sekali.

Sebagian besar responden (33\%) menyatakan kurang setuju jika bahasa dan sastra Sunda diajarkan hanya ketika akan menghadapi ujian atau THB, sebagian kecil responden $(11 \%)$ menyatakan tidak setuju, sebagian kecil responden lainnya (11\%) menyatakan biasa-biasa saja, dan sebagian responden lainnya lagi (25\%) menyatakan setuju sekali, serta sisanya (19\%) menyatakan setuju.

Sebagian besar responden (33\%) menyatakan kurang setuju jika buku sumber yang berbahasa Sunda di perpustakaan sekolah cukup lengkap, sebagian kecil responden (14\%) menyatakan tidak setuju, sebagian kecil responden lainnya (11\%) menyatakan biasa-biasa saja, dan sebagian responden lainnya lagi (22\%) menyatakan setuju sekali, serta sisanya (19\%) menyatakan setuju.

Sebagian besar responden (31\%) menyatakan setuju jika media pembelajaran atau alat peraga pembelajaran bahasa dan sastra Sunda di sekolah kurang lengkap, sebagian kecil responden (11\%) menyatakan setuju sekali, sebagian kecil responden lainnya (6\%) menyatakan biasa-biasa saja, dan sebagian responden lainnya lagi (28\%) menyatakan 
tidak setuju, serta sisanya (19\%) menyatakan kurang setuju.

Sebagian besar responden (67\%) menyatakan tidak setuju jika buku penunjang atau pendukung mata pelajaran bahasa dan sastra Sunda tidak ada, sebagian responden (17\%) menyatakan kurang setuju, sebagian responden lainnya (6\%) menyatakan biasa-biasa saja, dan sebagian responden lainnya lagi $(8 \%)$ menyatakan setuju, serta sebagian kecil responden $(3 \%)$ menyatakan setuju sekali.

Sebagian besar responden $(66 \%)$ menyatakan setuju sekali jika buku penunjang atau pendukung mata pelajaran bahasa dan sastra Sunda perlu disediakan oleh sekolah, sebagian responden $(25 \%)$ menyatakan setuju, sebagian kecil responden $(6 \%)$ menyatakan kurang setuju, dan sebagian kecil responden lainnya lagi (3\%) menyatakan tidak setuju.

Sebagian besar responden (36\%) menyatakan kurang setuju jika dalam melaksanakan pembelajaran bahasa dan sastra Sunda mengalami kesulitan, sebagian responden (14\%) menyatakan tidak setuju, sebagian responden lainnya (31\%) menyatakan setuju, dan sebagian responden lainnya lagi (14\%) menyatakan setuju sekali, serta sebagian kecil responden $(3 \%)$ menyatakan biasa-biasa saja.

Sebagian besar responden $(50 \%)$ menyatakan setuju sekali bahwa dalam mengajarkan bahasa dan sastra Sunda cukup lancar, sebagian kecil responden (8\%) menyatakan setuju sekali, sebagian kecil responden lainnya (3\%) menyatakan tidak setuju, dan sebagian responden lainnya lagi (17\%) menyatakan kurang setuju, serta sisanya (17\%) menyatakan biasa-biasa saja.

Sebagian besar responden (50\%) menyatakan setuju bahwa dirinya sangat senang dalam mengajarkan bahasa dan sastra Sunda kepada siswa, sebagian responden $(22 \%)$ menyatakan setuju sekali, sebagian kecil responden (17\%) menyatakan kurang setuju, dan sebagian kecil responden lainnya (11\%) menyatakan biasa-biasa saja.

Sebagian besar responden (44\%) menyatakan setuju ketika mengamati siswanya sangat senang mengikuti mata pelajaran bahasa dan sastra Sunda, sebagian responden (39\%) menyatakan biasa-biasa saja, sebagian responden lainnya (14\%) menyatakan sangat setuju, dan sebagian kecil responden lagi (3\%) menyatakan kurang setuju.

Sebagian besar responden (44\%) menyatakan setuju sekali jika di sekolah (SD/MI) ada guru khusus mata pelajaran bahasa dan sastra Sunda, sebagian responden $(33 \%)$ menyatakan setuju, sebagian responden lainnya (8\%) menyatakan kurang setuju, dan sebagian kecil responden $(6 \%)$ menyatakan biasabiasa saja, serta tidak ada satu pun responden yang menyatakan tidak setuju.

Sebagian besar responden (44\%) menyatakan setuju tentang pentingnya penggunaan bahasa Sunda sebagai bahasa pengantar di sekolah tingkat rendah, sebagian responden (39\%) menyatakan sangat setuju, sebagian kecil responden (8\%) menyatakan biasa-biasa saja, dan sebagian kecil responden lainnya (8\%) menyatakan kurang setuju, serta tidak ada satu pun responden yang menyatakan tidak setuju.

Sebagian besar responden (50\%) menyatakan kurang setuju jika bahasa Sunda digunakan di lingkungan keluarga dan dicampur dengan bahasa lain, sebagian responden $(25 \%)$ tidak setuju, sebagian responden lainnya(14\%) menyatakan setuju, dan sebagian kecil responden $(8 \%)$ menyatakan biasa-biasa saja, serta sebagian kecil responden lainnya (3\%) menyatakan setuju sekali.

Tentang penggunaan bahasa Indonesia sebagai bahasa pengantar dalam mengajarkan bahasa dan sastra Sunda, prosentase responden yang setuju, biasabiasa saja, dan kurang setuju sama 
besarnya (22\%), sedangkan sebagian responden lainnya ((19\%) menyatakan tidak setuju, dan sebagian kecil responden (14\%) menyatakan setuju sekali.

Sebagian besar responden (36\%) menyatakan kurang setuju jika mereka tidak mengetahui tentang peraturan penggunaan bahasa dan sastra Sunda di kelas-kelas awal SD, sebagian responden (31\%) menyatakan setuju, sebagian responden lainnya (11\%) menyatakan setuju sekali, dan sebagian responden lainnya lagi (11\%) menyatakan biasa-biasa saja, serta sebagian kecil responden (8\%) menyatakan tidak setuju.

Sebagian besar responden (64\%) menyatakan setuju sekali bahwa penataran dan penyuluhan bahasa dan sastra Sunda perlu dilaksanakan bagi para guru, dan sebagian responden lainnya (36\%) menyatakan setuju, serta tidak ada satu pun responden yang menyatakan kurang atau tidak setuju.

\section{SIMPULAN}

Berdasarkan analisis data pada bab IV, temuan penelitian ini dapat disimpulkan sebagai berikut.

1) Jumlah sekolah SMP/MTs di Jawa Barat adalah 588 negeri dan 1.979 swasta. Secara keseluruhan jumlah SMA/MA dan SMK di Jawa Barat berjumlah 3.967 sekolah.

2) Jumlah siswa SMP/MTs di Jawa Barat adalah SMP/MTs Negeri 76.076 siswa dan SMP/MTs swasta 50.298 siswa. Secara keseluruhan siswa SMP/MTs di Jawa Barat berjumlah 236.850 siswa.

3) Jumlah romobongan belajar SMP/MTs adalah 126.374 rombel dan SMK 126.374 rombel.

4) Kebutuhan guru bahasa Sunda di SMP/MTs 296 guru dan di SMK 301 guru.

Berdasarkan kesimpulan di atas, dalam penelitian disampaikan beberapa saran berikut ini.
1) Perlu dilakukan pendataan guru bahasa Sunda dengan menggunakan sistem digital mapping guru agar semua guru dapat diakses.

2) Penelitian ini masih bersifat studi dokumentaasi, oleh kerena itu perlu dilakukan penelitian lanjutan yang lebih mendalam dan akurat.

\section{PUSTAKA RUJUKAN}

Departemen Pendidikan Nasional. (2003). Undang-Undang Nomor 20 Tahun 2003. Tentang Sistem Pendidikan Nasional, Jakarta: Depdiknas.

Departemen Pendidikan Nasional. (2005). Undang-Undang Nomor 14 Tahun 2005, Tentang Guru dan Dosen. Jakarta: Depdiknas.

Departemen Pendidikan Nasional. (2005). Peraturan Pemerintah Nomor 19 Tahun 2005, tentang Standar Nasional Pendidikan. Jakarta: Depdiknas.

Mariana, Anna. (2002). Profil Kompetensi Profesional Guru SLTP (Studi Kasus Terhadap Kinerja Guru di SLTP Negeri 50 Bandung). Tesis S2 Pada Program Studi Administrasi Pendidikan PPS UPI Bandung: Tidak diterbitkan

Natawidjaja, Rochman. (1988). Pengolahan Data Secara Statistik. Bandung: PPS.

Stephen, Isaac dan William B., Michael. (1981). Hand Book in Research and Evaluation, 2nd Edition. San Diego, California: Edit Publishers

Umaedi. (1999). Manajemen Peningkatan Mutu Berbasis Sekolah. Ditjen Dikdasmen Depdikbud. Jakarta.

\section{UCAPAN TERIMA KASIH}

Penulis mengucapkan terima kasih kepada penyunting jurnal Lokabasa atas dimuatnya tulisan ini. 